\title{
Uji daya hambat ekstrak daun stevia (Stevia rebaudiana Bertoni M.) terhadap pertumbuhan Staphylococcus aureus secara in vitro
}

\author{
${ }^{1}$ Yaromis Wenda \\ ${ }^{2}$ Pemsi M. Wowor \\ ${ }^{2}$ Michael A. Leman \\ ${ }^{1}$ Kandidat Skripsi Program Studi Pendidikan Dokter Gigi Fakultas Kedokteran \\ ${ }^{2}$ Bagian Farmakologi dan Terapi Fakultas Kedokteran \\ ${ }^{3}$ Program Studi Pendidikan Dokter Gigi Fakultas Kedokteran \\ Universitas Sam Ratulangi Manado \\ Email: wenda454@gmail.com
}

\begin{abstract}
Currently, oral health requires comprehensive handling by dentists and other health professionals. Osteomyelitis is an infection that occurs in bone tissue and bone marrow of the jaw and/or cortical bones, predominantly caused by Staphylococcus aureus. Medicinal plants in Indonesia have been widely used as traditional medicine inter alia stevia (Stevia rebaudiana Bertoni M.). This stevia plant has components that are typical natural sweetener and stevioside which has the characteristics as antibacterial, antiviral, anti-inflammatory, antimicrobial, and antifungal, and other active substances including tannins, alkaloids, flavonoids, and phenol. This was an experimental laboratory study with the post test only group design. Subjects were Staphylococcus aureus bacteria. The results showed that stevia leaf extract had inhibition zone to Staphylococcus aureus growth of $10.32 \mathrm{~mm}$ which was categorized as strong according to Davis and Stout 1971. Conclusion: Stevia leaf extract (Stevia rebaudiana Berrtoni M.) had strong inhibition to Staphylococcus aureus.
\end{abstract}

Keywords: osteomyelitis, stevia (Stevia rebaudiana Bertoni M.), Staphylococcus aureus

\begin{abstract}
Abstrak: Dewasa ini kesehatan gigi dan mulut memerlukan penanganan secara komperhensif oleh dokter gigi maupun tenaga kesehatan lainnya. Salah satu penyakit yang sering dijumpai yaitu osteomielitis pada jaringan tulang dan sum-sum tulang rahang dan/atau korteks tulang dengan penyebab utama ialah bakteri Staphylococcus aureus. Tanaman herbal di Indonesia telah banyak digunakan sebagai obat tradisional; salah satunya ialah tanaman stevia (Stevia rebaudiana Bertoni M.). Tanaman stevia memiliki komponen yang bersifat pemanis alami, stevioside yang berefek antibakteri, antivirus, antiinflamasi, antifungsi, dan antimikroba, serta zat aktif di antaranya ialah tannin, alkaloid, flavonoid, dan fenol. Jenis penelitian ini ialah eksperimental laboratorik dengan post test only group design. Subyek penelitian ialah bakteri Staphylococcus aureus. Hasil penelitian memperlihatkan bahwa ekstrak daun stevia (Stevia rebaudiana Bertoni M.) mempunyai rerata zona hambat terhadap pertumbuhan bakteri Staphylococcus aureus sebesar 10,32 mm yang tergolong kuat menurut Davis dan Stout 1971. Simpulan: Ekstrak daun stevia (Stevia rebaudiana Berrtoni M.) memiliki daya hambat yang kuat terhadap bakteri Staphylococcus aureus.
\end{abstract}

Kata kunci: osteomielitis, stevia (Stevia rebaudiana Bertoni M.), Staphylococcus aureus

Kesehatan gigi dan mulut pada masyarakat merupakan suatu masalah yang saat ini memerlukan penanganan secara komprehensif baik oleh dokter gigi maupun tenaga kesehatan lainnya. Dalam praktek dokter gigi sering dijumpai penyakit-penyakit gigi dan mulut pada masyarakat, di antaranya osteomielitis pada tulang rahang yang memiliki persentase sekitar 20\%-50\%. ${ }^{1,2}$ Osteomielitis merupakan penyakit infeksi pada jaringan tulang dan sum- 
Wenda, Wowor, Leman: Uji daya hambat ekstrak daun stevia ..

sum tulang rahang dan/atau korteks tulang, yang dapat disebabkan oleh bakteri, virus, atau mikroorganisme lainnya. ${ }^{2}$ Bakteri yang paling dominan berperan dalam terjadinya penyakit ini ialah Staphylococcus aureus (70\%-80\%). ${ }^{3}$

Infeksi Staphylococcus aureus menyebabkan terbentuknya suatu kantung berisi nanah di dalam sum-sum tulang rahang, lebih sering terjadi di mandibula, dan dapat menyebar melalui pembuluh darah di sum-sum tulang rahang. Jika tidak segera diobati, maka hal ini dapat menyebabkan komplikasi serius yaitu osteomielitis akut berlanjut menjadi kronis. ${ }^{3,4}$ Pengobatan yang tidak adekuat menghasilkan suatu masalah baru seperti resistensi terhadap antibiotik. Pada tahun 1961, penisilin semisintetik seperti methisilin (methicillin), dikembangkan untuk memecahkan masalah resistensi terhadap antibiotik penisilin namun, telah dilaporkan bahwa Staphylococcus aureus telah resisten terhadap methisilin sehingga dikenal dengan Methicillin-Resistant Staphylococcus aureus (MRSA). ${ }^{4,5}$

Salah satu cara alternatif mengurangi masalah resistensi yaitu dengan memanfaatkan bahan alami bagi kesehatan, terutama obatobatan yang berasal dari tumbuhan karena pengobatan tradisional dengan menggunakan bahan alami lebih murah, mudah didapat, dan memiliki efek samping minimal. ${ }^{6}$ Salah satu tumbuhan obat alami yaitu stevia (Stevia rebaudiana Bertoni M.) merupakan famili dari Sterceae, pemanis alami 200-300 kali dari sukrosa, dan memiliki manfaat lain sebagai antibakteri, antivirus, antiinflamasi, antimikroba, dan antifungsi. ${ }^{6,7}$

Tanaman stevia telah lama dikenal di perbatasan Paraguay, Argentina dan Brasil yaitu distrik Amabai dan Iquaqu. Tanaman stevia (Stevia rebaudiana Bertoni M.) diperkirakan masuk ke Indonesia pada tahun 1977 atas kerja sama penguasa Jepang di Indonesia. ${ }^{7}$ Pemanfaatan tanaman stevia hingga saat ini hanya sebagai bahan dasar gula. Tanaman stevia berefek sebagai antibakteri karena adanya senyawa bioaktif seperti stevioside, alkaloid, flavonoid, dan tannin. ${ }^{8}$ Dari penelitian yang dilakukan oleh Astri tahun 2014 terhadap Streptococcus mutans bahwa ekstrak daun stevia (Stevia rebaudiana Bertoni M.) dalam pengukuran kadar daya hambat maksimal $80 \%$, terbukti efektif menghambat pertumbuhan bakteri Streptococus mutans penyebab karies. Namun, ekstrak daun Stevia (Stevia rebaudiana Bertoni M) belum pernah diujikan ke bakteri Staphylococcus aureus. Berdasarkan latar belakang di atas, peneliti ingin melakukan penelitian uji daya hambat ekstrak daun Stevia (Stevia rebaudiana Bertoni M) terhadap pertumbuhan Staphylococcus aureus.

\section{BAHAN DAN METODE}

Jenis penelitian ialah eksperimental murni (true experimental) dengan post test only control group design. Penelitian dilakukan di Laboratorium Farmasi Fakultas MIPA dan Laboratorium Mikrobiologi Fakultas Kedokteran Universitas Sam Ratulangi pada bulan Maret 2016-Agustus 2016.

Subjek penelitian ialah bakteri Staphylococcus aureus yang dibiakkan dari abses rongga mulut di Laboratorium Mikrobiologi Farmasi Fakultas FMIPA Universitas Sam Ratulangi. Daun stevia (Stevia rebaudiana Bertoni M.) didapatkan dari Kota Tomohon, Sulawesi Utara dan diekstrak dengan menggunakan etanol 96\%.

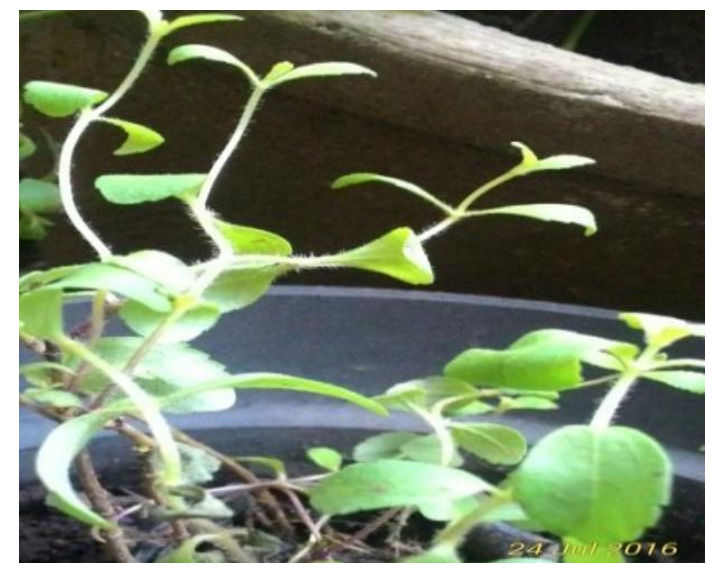

Gambar 1. Daun stevia (Stevia rebaudiana Bertoni M.)

Metode pengujian yang digunakan ialah metode modifikasi Kirby-Bauer menggunakan cawan Petri. Media MHA disediakan sebanyak lima cawan petri dengan 15 buah sumur. Setiap cawan Petri berisi satu sumur kelompok intervensi, satu sumur kelompok kontrol positif, dan satu sumur kelompok kontrol negatif. selanjutnya cawan Petri diinkubasi dalam inkubator pada suhu $37^{\circ} \mathrm{C}$ selama 24 jam. Pengamatan dilakukan setelah 24 jam masa inkubasi. Zona bening merupakan petunjuk kepekaan bakteri terhadap bahan antibakteri yang digunakan sebagai bahan uji dan dinyatakan dengan diameter zona hambat. 
Zona hambat yang terbentuk di sekitar sumur diukur diameter vertikal dan diameter horizontal dalam satuan millimeter $(\mathrm{mm})$ dengan menggunakan jangka sorong (Gambar 1). Rumus pengukuran zona hambat ialah sebagai berikut:

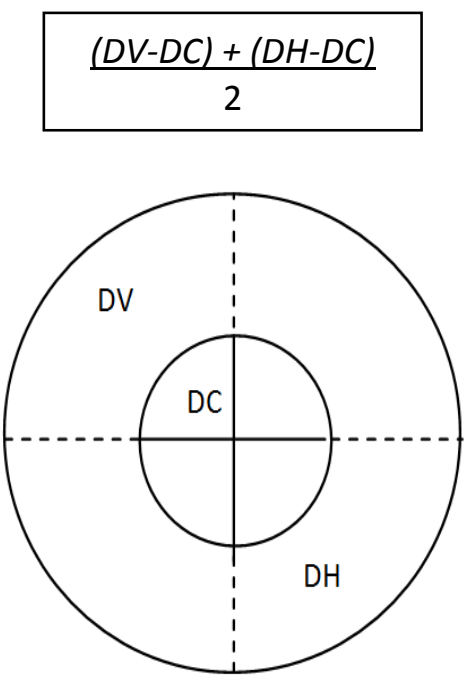

Gambar 1.Pengukuran diameter zona hambat
Keterangan :

\begin{tabular}{ll}
\hline & $:$ Zona hambat \\
\hline DV & : Diameter vertikal \\
DH & : Diameter Horizontal \\
DC & : Diameter Cakram
\end{tabular}

\section{HASIL PENELITIAN}

Pada uji daya hambat ekstrak daun Stevia (Stevia rebaudiana Bertoni $\mathrm{M}$ ) terhadap pertumbuhan bakteri Staphylococcus aureus, dalam satu cawan Petri terdapat tiga perlakuan yang diberikan dan dilakukan lima kali pengulangan. Kertas saring yang diberi ekstrak daun stevia (Stevia rebaudiana Bertoni M) dan clindamycin memiliki zona hambat yang berbeda, sedangkan kertas saring yang diberi akuades tidak memiliki zona hambat. Diameter zona hambat yang terbentuk, dihitung dengan rumus luas diameter zona hambat dan hasil pengukuran dilihat pada Tabel 1.

Tabel 1. Hasil pengukuran diameter zona hambat ekstrak daun Stevia (Stevia rebaudiana Bertoni M.), clindamycin, dan akuades terhadap pertumbuhan bakteri Staphylococcus aureus

\begin{tabular}{cccc}
\hline Pengulangan & \multicolumn{2}{c}{ Diameter zona hambat } & \\
& $\begin{array}{c}\text { Ekstrak daun stevia } \\
\text { (Stevia rebaudiana } \\
\text { Bertoni M.) }\end{array}$ & $\begin{array}{c}\text { Kontrol positif } \\
\text { (Clindamycin) }\end{array}$ & $\begin{array}{c}\text { Kontrol negatif } \\
\text { (Akuades) }\end{array}$ \\
\hline 1 & 9,22 & 12,95 & 0 \\
2 & 11,29 & 14,94 & 0 \\
3 & 9,38 & 14,97 & 0 \\
4 & 11,02 & 14,41 & 0 \\
5 & 9,25 & 5,70 & 0 \\
Rerata & $\mathbf{1 0 , 3 2}$ & $\mathbf{1 4 , 5 9}$ & $\mathbf{0}$ \\
\hline
\end{tabular}

\section{BAHASAN}

Berdasarkan hasil pengamatan dari lima kali pengulangan, diameter zona hambat yang terbentuk bervariasi. Variasi diameter zona hambat yang dihasilkan dalam penelitian ini dapat disebabkan oleh perbedaan jumlah larutan isolat ekstrak daun Stevia (Stevia rebaudiana Bertoni $\mathrm{M}$ ) dan jumlah larutan clindamycin yang diserap oleh masing-masing kertas saring yang terdapat pada 5 cawan Petri berbeda. Hal ini sesuai dengan pendapat Gillespie yang menyebutkan bahwa kelemahan metode kertas saring yaitu tidak dapat diketahui secara pasti jumlah larutan yang diserap oleh masing-masing kertas saring., ${ }^{9,10}$

Penyebab yang kedua yaitu jumlah bakteri Staphylococcus aureus yang tersebar pada media Muller Hinton Agar (MHA) tidak merata di tiap area pada masing-masing cawan Petri. Hal ini mungkin disebabkan karena pada saat pengapusan bakteri Staphylococcus aureus menggunakan dry glass, sebagian Staphylococcus aureus menempel pada area tertentu di media Muller Hinton Agar (MHA) yang menyebabkan penyebarannya tidak merata, sehingga diperoleh daya hambat yang berbeda. 
Hal ini juga sesuai dengan pendapat Gillespie, dimana kelemahan metode kertas saring tergantung pada bakteri yang diinokulasikan pada media. Bakteri yang tidak tersebar merata pada media dapat memengaruhi diameter zona hambat yang terbentuk. ${ }^{9}$

Hasil dari zona hambat yang terbentuk pada kertas saring ekstrak daun Stevia (Stevia rebaudiana Bertoni M.) disebabkan karena adanya senyawa aktif daun stevia dengan aktivitas antibakteri yang dapat menghambat pertumbuhan bakteri Staphylococcus aureus. Mekanisme kerja senyawa aktif tersebut yaitu dengan merusak komponen penting dari dalam sel bakteri yang akhirnya menyebabkan kematian sel bakteri, ${ }^{11,12}$ sedangkan clindamycin bekerja dengan menghambat sintesis protein, menghambat translokasi ribosomal, serta berikatan dengan ribosom RNA dari subunit ribosom bakteri, sehingga dapat menghambat pertumbuhan bakteri Stahpylococcus aureus. ${ }^{11} 13$

Nilai diameter zona hambat ekstrak daun stevia (Stevia rebaudiana Bertoni M) dan clindamycin yang terbentuk hampir sama. Besarnya rerata zona hambat yang dibentuk ekstrak daun stevia (Stevia rebaudiana Bertoni M.) dan clindamycin tergolong kuat dalam penggolongan Davis dan Stout 1971. ${ }^{14}$ Penelitian ini dapat menunjukkan potensi yang ada di dalam daun stevia (Stevia rebaudiana Bertoni M.).

\section{SIMPULAN}

Ekstrak daun stevia (Stevia rebaudiana Bertoni M.) memiliki daya hambat yang kuat terhadap pertumbuhan bakeri Staphylococcus aureus.

\section{SARAN}

Diharapkan dapat dilakukan penelitian lebih lanjut mengenai daya hambat ekstrak daun stevia (Stevia rebaudiana Bertoni M) terhadap bakteri Gram positif lainnya, serta kadar hambat minimum dan kadar bunuh minimum ekstrak daun stevia (Stevia rebaudiana Bertoni M) terhadap bakteri Staphylococcus aureus.

\section{DAFTAR PUSTAKA}

1. Mansjoer A. Kapita Selekta Kedokteran (4th ed). Jakarta: Media Aesculapius FKUI, 2010; p. 35- 41.

2. Reeves CJ, Roux G, Lockhart R. Keperawatan Medikal Bedah. Jakarta: Salemba Medika, 2001; p. 8- 15.

3. Ovedoff D. Kapita Selekta Kedokteran Jilid 2. Jakarta: Binarupa Aksara, 2002; p. 158.

4. Corwin EJ. Buku Saku Patofisiologi (3rd ed). Jakarta: EGC, 2009; p. 51.

5. Shear M. Kista Rongga Mulut (3rd ed). Jakarta: EGC, 2008; p. 233-4.

6. Black JM. Medical Surgical Nursing: Clinical Management for Positve Outcomes (8th ed). Michigan: Elsevier Saunders, 2005.

7. Tucker SM. Standar Perawatan Pasien: Proses Keperawatan, Diagnosis dan Evaluasi. (5th ed). Cetakan 1. Jakarta: EGC, 1999.

8. Nester EW, Anderson DG, Roberts CE, Pearsall NN, Nester MT, Hurley D. Microbiology A Human Perspective (4th ed). New York: McGraw-Hill, 2004.

9. Warsa UC. Kokus positif Gram (Staphylococcus). In: Staf Pengajar Bagian Mikrobiologi Fakultas Kedokteran Universitas Indonesia, editor. Buku Ajar Mikrobiologi Kedokteran (Edisi Revisi). Tangerang: Binarupa Aksara, 2009; p. 125-34.

10. Kusuma SAF. Staphylococcus aureus [Makalah]. Jatinangor: Fakultas Farmasi Universitas Padjadjaran; 2009.

11. Andryana VAAP. Pengaruh daya antibakteri ektrak daun stevia (Stevia rebaudiana Bertoni) pada konsentrasi $5 \%, 10 \%, 20 \%, 40 \%$ dan $80 \%$ terhadap Streptococus mutans (in vitro) [Naskah publikasi]. Surakarta: FKG Universitas Muhammadiyah Surakarta; 2014.

12. Pelczar MJ, Chan ES. Dasar-dasar Mikrobiologi (2nd ed). Jakarta: Universitas Indonesia, 1988; p. 10-8.

13. Maretta V. Pemanfaatan daun stevia (Stevia rebaudiana Bertoni) sebagai pemanis alami terhadap kualitas organoleptik dan nilai gizi bolu kukus [Skripsi]. Surakarta: UMS; 2011.

14. Davis WW, Stout TR. Disc plate method of microbiological antibiotic aassay. Appl Microbiol. 1971;22(4):659-65. 